\title{
Supporting Research-Inspired Entrepreneurial Activities in India
}

Nikhil A. Gokhale

\author{
"Cherish creativity, be bold, and have") \\ the audacity to seek and discover. \\ Never lose your nerve!
}

\author{
Alan J. Heeger \\ Nobel Laureate in Chemistry (2000)
}

\begin{abstract}
Nations built on innovation, entrepreneurship, and production are able to dominate the world economy. However, risk taking has traditionally been discouraged in developing nations. The uncertainty and financial insecurity associated with entrepreneurial activities are the greatest barriers that budding entrepreneurs need to overcome in order to transition into successful entrepreneurs. This challenge needs substantial effort and steady support from society. Easy access to information, mentorship, and a network of venture capitalists and angel investors also play critical roles in promoting entrepreneurial activities. To this end, the Government of India recently launched a nationwide campaign to promote entrepreneurial activities across the country. Some of the recently emerging trends indicate that scientific and technological innovators from India are now willing to be a part of the global entrepreneurial revolution. Research-inspired entrepreneurial initiatives are expected to play a key role in facilitating India's economic growth in the coming years. This article focuses on the initiatives undertaken by the Indian Government and by various academic institutes to facilitate entrepreneurial activities across the country.
\end{abstract}

\section{Introduction}

Entrepreneurship is defined as the ability to develop a business model in an attempt to find a creative solution to an existing problem, quite often using limited resources (Stevenson, 1983). Thus, entrepreneurs are path creators rather than path seekers, and they benefit from an ever-present sense of urgency (Bhide, 1994). The ability to take risks is an essential attribute seen in most entrepreneurs (MacKo \& Tyszka, 2009), regardless of the area of expertise. Although most developed countries primarily focus on technology-driven entrepreneurial initiatives, many people in economically developing countries are essentially forced into less technologically focused forms of entrepreneurship as their only opportunity for self-employment (Singer et al., 2015). Recent trends, however, indicate that research-inspired entrepreneurial ventures (i.e., innovative business ideas that are the direct offshoots of scientific and technological breakthroughs) are on the rise in many developing and developed nations. Many universities from around the world have recently started supporting incubation facilities and training cells for innovators who wish to become successful entrepreneurs (Pattnaik et al., 2014). Science- and technology-driven innovations are now being patented and commercialized by universities and research institutes from around the world (Hartmann, 2014). Researchers from developing countries such as India are now exploring new opportunities for commercializing their innovations.

This article provides an overview of the trend towards research-inspired entrepreneurship in India. It characterizes the India entrepreneur and outlines various governmental and academic initiatives to foster entrepreneurship in a culture that has traditionally been more focused on seeking steady employment than risk taking. It concludes with a mix of optimism and caution: if the challenges can be overcome and the opportunities can be taken, the scene is set for Indian entrepreneurs to redefine and reinvigorate the Indian economy. 


\section{Supporting Research-Inspired Entrepreneurial Activities in India}

Nikhil A. Gokhale

\section{Research-Inspired Entrepreneurship}

Recent advances in science and technology have opened up new avenues for the commercialization of innovative products and services. The research community is increasingly becoming aware of the benefits of patent protection, licensing, and innovation-driven entrepreneurship. In India, budding researchers are increasingly publishing their work in reputable journals and seeking patent protection only for meaningful and commercially viable innovations. Funding agencies in India and abroad are now giving higher priority to innovations that can have a direct impact on the field, either through high-impact publications or through marketable patents. The ultimate goal is for research activities to make an impact on society - and not simply contribute to the vast number of patents and publications lying unnoticed in the ever-increasing database of global innovations.

On a related note, highly skilled Indian scientists and engineers educated in North American and European universities are increasingly returning to India because of a sudden increase in the demand for such researchers from government, academic, and industrial laboratories spread across the country. Many of the science and technology researchers, who previously preferred to remain confined inside their research laboratories, are now attempting to commercialize their inventions. Easy access to information, higher Internet speeds, and efficient business networking (Habiby \& Coyle, 2010) have now made it possible for entrepreneurshipsupporting communities to spread awareness about the importance of entrepreneurial ventures. Indian universities and national institutes have now started investing time and resources to motivate researchers to transform themselves into promising entrepreneurs. As an example, RK University in Rajkot, India, organized an International Conference on Research \& Entrepreneurship in January 2016 (ICRE 2016; rku.ac.in/fdsr/icre/) to create a platform for researchers to interact with Indian and North American experts and entrepreneurs. Many distinguished researchers and entrepreneurs from India and abroad attended this event. Chemistry Nobel Laureate Dr. Alan J. Heeger (himself a technology entrepreneur) delivered a recorded keynote speech on the importance of research-inspired entrepreneurship. Similar initiatives and longer-term programs are also being increasingly undertaken by various other universities and institutes in India, examples of which will be provided in the section that follows.

\section{The Indian Entrepreneur}

Traditionally, most Indian families have encouraged their children to take up jobs in the government, academia, or industry. Risk taking and entrepreneurship have mostly been confined to certain geographical regions of India. The Indian state of Gujarat is aptly referred to as the land of entrepreneurship, because of the large number of entrepreneurs it has produced, including a large number of women entrepreneurs (Shastri \& Rao, 2014). Over the years, the state has also exported thousands of entrepreneurs to a large number of countries around the world. The most popular entrepreneurial innovators in India include Narayana Murthy, the founder of Infosys (infosys.com), Kiran Mazumdar-Shaw, the founder of Biocon (biocon.com), and the co-founders of Flipkart (flipkart.com), Binny Bansal and Sachin Bansal. All of them had the right technical background to launch their companies. Several other technologybased companies in India were founded by people who did not have deep technical expertise in the related subject area. Varaprasad Reddy's Shantha Biotechnics (shanthabiotech.com), now owned by Sanofi (Frew et al., 2007), serves as an example of a small Indian research startup that obtained global recognition, after certain initial struggles. Shantha Biotechnics started as a research outfit in the Osmania University campus and was subsequently able to commercialize India's first low-cost (recombinant-DNA-based) Hepatitis-B vaccine (Chakma et al., 2011).

The technically competent Indian entrepreneur is increasingly receiving support from startup incubators spread across the country. Examples include:

1. The Centre for Innovation, Incubation, and Entrepreneurship (CIIE; ciie.co) at the Indian Institute of Management in Ahmedabad works in close collaboration with industry and with the Indian Government's Department of Science \& Technology (DST; dst.gov.in) to actively catalyze the rapid commercialization of business ideas.

2. The Indian Institute of Technology Bombay's Society for Innovation \& Entrepreneurship (SINE; sineiitb.org) provides support to technology-based innovations. Spread over an area of 10,000 square feet, SINE has also received support from the DST.

3. Venture Center (venturecenter.co.in), a initiative of the Council for Scientific \& Industrial Research (CSIR; 


\section{Supporting Research-Inspired Entrepreneurial Activities in India}

\section{Nikhil A. Gokhale}

csir.res.in), predominantly focuses on the commercialization of technologies related to material science, chemical synthesis, biomedical research, and chemical engineering. The Venture Center receives support from the National Science \& Technology Entrepreneurship Development Board (NSTEDB; nstedb.com), a body functioning under the aegis of the DST.

4. IIT Kharagpur's Science \& Technology Entrepreneurship Park (STEP; step-iitorg) provides support to new ventures during their initial growth phase.

5. IIM Bangalore's Nadathur S. Raghavan Center for Entrepreneurial Learning (NSRCEL; nsrcel.org) offers training to promising entrepreneurs.

6. The International Centre for Entrepreneurship \& Technology (iCreate; icreate.org.in) in Gujarat provides incubation and guides entrepreneurs through mentorship, workshops, and seminars focused on building the entrepreneurial spirit and enabling the growth of existing companies.

7. The Indian Angel Network (indianangelnetwork.com) is a network of angel investors that provide funding, mentoring, and market access to early-stage ventures.

8. Khosla Ventures (khoslaventures.com) provides financial backing for solutions to large problems that are amenable to technology solutions.

Besides the examples listed above, a large number of other startup incubators have already been set up or are currently being set up across India and the number is expected to rise steadily in the next ten to fifteen years.

\section{Government Initiatives for Indian Entrepreneurs}

Under the leadership of Prime Minister Narendra Modi, the Government of India has recently launched several schemes for facilitating the establishment of entrepreneurial ventures across India. The "Make in India" (makeinindia.com) initiative aims to build an environment that is favourable to inventors, entrepreneurs, investors, and manufacturers. The initiative makes it significantly easier for product manufacturers to obtain industrial licenses, and the overall process has been streamlined to cater to the basic needs of the manufacturing industry. The government also has plans to build "smart cities" in India's industrial corridors. Besides encouraging foreign direct investment, the government is also keeping funds aside for infrastructure development.

The Department of Electronics and Information Technology's (DeitY's) Technology Incubation and Development of Entrepreneurship (TIDE; tinyurl.com/zfbwg43) program is yet another example of how the government is trying to provide support to new technology business incubators and technology-driven entrepreneurship. Under the TIDE scheme, DeitY is facilitating productoriented innovation, attempting to bridge the gap between research and commercialization, providing training to budding entrepreneurs, promoting the involvement of research faculty in startup businesses, and reinforcing the linkages between academia and industry. The TIDE centres have also been empowered to offer financial assistance for incubation and infrastructure improvement.

In January 2016, Prime Minister Modi officially launched the Startup India (startupindia.gov.in) campaign. The most prominent highlights of this pro-entrepreneurship campaign include simplified e-registration, selfcertification, reduced patent application fees, fasttracked patent applications for new India startups, an easy exit policy, financial support, income tax relaxation for the first three years, special benefits for female applicants, and pedagogical support for students. The Startup India campaign also puts special emphasis on innovation-driven entrepreneurial ventures. The campaign will also organize startup festivals to showcase India's research-inspired entrepreneurial initiatives and to connect entrepreneurial innovators with mentors, technology incubators, and investors. Research parks, startup centres, and technology business incubators will be set up across the country at premier institutes. Student innovators will be benefit from a platform to showcase their work in order to secure adequate funding for their entrepreneurial innovation.

In summary, the Indian Government is enthusiastically supporting science- and technology-driven entrepreneurial initiatives and making it easier for budding researchers to transform themselves into successful entrepreneurs.

\section{Conclusion}

The traditionally job-seeking Indian research community is rapidly developing profound interest in commercializing their technology-driven innovations. The 


\section{Supporting Research-Inspired Entrepreneurial Activities in India}

\section{Nikhil A. Gokhale}

Indian Government is also investing significant resources into supporting entrepreneurship and is putting special emphasis on promoting research-inspired entrepreneurial initiatives. Indian and multinational companies have started showing great enthusiasm in supporting the Indian government's policies that would help India attain a more visible position on the global entrepreneurial map. The "Make in India" and "Startup India" programs have clearly outlined a detailed roadmap that would encourage researchers to turn their innovations into successful businesses.

Entrepreneurial innovators are now receiving the much-needed support required for overcoming the initial hesitation, uncertainty, and financial risks associated with startup ventures. A large cross-section of the Indian society has now started giving social recognition to budding technology entrepreneurs. Although the overall environment seems conducive to entrepreneurship, it remains to be seen whether the Indian innovators will try to make the most of every opportunity. India's budding scientists and engineers now need to focus their attention on originality and stay away from derivative work. India's innovators need to show a sense of urgency when it comes to launching scienceand technology-driven entrepreneurial ventures. Merely proposing ground-breaking ideas is not enough.

On the positive side, several highly skilled researchers are returning to India to take up research positions in government, academic, and industrial laboratories. This rapid influx of highly skilled scientists and engineers is expected to give a boost to innovation (and possibly to entrepreneurship in the long run). Renowned universities and national institutes of repute spread across India are now establishing incubators to facilitate technology-driven startups. The Indian Government is also taking drastic measures to support research-inspired entrepreneurial initiatives. India is undergoing a dramatic transition and Indian innovators are attempting to catch up with the global leaders in the entrepreneurial sector by making use of their scientific and engineering skills. If the current trend continues, then the Indian economy is expected to reap the benefits of science- and technology-driven entrepreneurial initiatives in the coming years.

\section{About the Author}

Nikhil A. Gokhale is Associate Director of the Faculty of Doctoral Studies \& Research at RK University in Rajkot, India. He obtained his Master's degree from the University of Pune, India, and moved to the United States to pursue his $\mathrm{PhD}$ in Chemistry (Biochemistry) at the University of Illinois at Chicago. He then joined the U.S. National Institutes of Health (NIH) as a Visiting Fellow to study the inositol phosphate-/pyrophosphate-based inhibition of proteins involved in cancer and inflammation. After conducting biomedical research at the NIH and at the University of Massachusetts Medical School, Dr. Gokhale returned to the University of Illinois at Chicago as a Visiting Research Assistant Professor. His research interests have focused on the field of biochemistry and signal transduction.

\section{References}

Bhide, A. 1994. How Entrepreneurs Craft Strategies that Work. Harvard Business Review, 72(2): 150-161.

Chakma, J., Masum, H., Perampaladas, K., Heys, J., \& Singer, P. A. Indian Vaccine Innovation: The Case of Shantha Biotechnics. Globalization and Health, 7(9).

http://dx.doi.org/10.1186/1744-8603-7-9

Frew, S. E., Rezaie, R., Sammut, S. M., Ray, M., Daar, A. S., \& Singer, P. A. India's Health Biotech Sector at a Crossroads. Nature Biotechnology, 25(4): 403-417.

http://dx.doi.org/10.1038/nbt0407-403

Habiby, A. S., \& Coyle, D. M. 2010. The High-Intensity Entrepreneur. Harvard Business Review, 88(9): 74-78.

Hartmann, D. 2014. Turning Technology into Business Using University Patents. Technology Innovation Management Review, 4(12): 37-43.

http://timreview.ca/article/856

MacKo, A., \& Tyszka, T. 2009. Entrepreneurship and Risk Taking. Applied Psychology, 58(3): 469-487. http://dx.doi.org/10.1111/j.1464-0597.2009.00402.x

Pattnaik, P. N., \& Pandey, S. C. 2014. University Spinoffs: What, Why, and How? Technology Innovation Management Review, 4(12): 44-50.

http://timreview.ca/article/857 


\section{Supporting Research-Inspired Entrepreneurial Activities in India}

Nikhil A. Gokhale

Shastri, D., \& Rao, U. T. 2014. Women Entrepreneurs of Gujarat. Procedia Economics and Finance, 11: 745-752.

http://dx.doi.org/10.1016/S2212-5671(14)00238-X

Singer, S., Amorós, E., \& Moska, D. 2015. Global Entrepreneurship Monitor: 2014 Global Report. London: Global Entrepreneurship Research Association.

http://gemconsortium.org/report/49079

Stevenson, H. H. 1983. A Perspective on Entrepreneurship. Harvard Business School Background Note 384-131. Boston, MA: Harvard Business School.
Citation: Gokhale, N. A. 2016. Supporting ResearchInspired Entrepreneurial Activities in India. Technology Innovation Management Review, 6(5): 10-14.

http://timreview.ca/article/986

Keywords: entrepreneurship, research-inspired entrepreneurship, financial risk, business, economy 